\title{
The determinants factors of accounting practitioner's attitude towards the use of Malaysian Business Reporting System (MBRS)
}

\author{
Roslee Bin Uyob ${ }^{1}$, Ku Maisurah Binti Ku Bahador ${ }^{2}$ and Nor Syahridah Binti Noh ${ }^{3}$ \\ ${ }^{1,3}$ Department of Commerce, Politeknik Sultan Abdul Halim Muadzam Shah (POLIMAS), \\ Jitra Kedah, Malaysia. \\ ${ }^{2}$ Tunku Puteri Intan Safinaz School of Accountancy, \\ Universiti Utara Malaysia.
}

\begin{abstract}
MBRS is a new submission platform introduce by SSM that enable the submission filings in XBRL format in Malaysia. However, since the introducing of SSMxT in 2014, the issue of XBRL format adoption by companies in Malaysia is still questionable especially regarding the attitude of potential users towards the use of XBRL format. Therefore, this study is try to examine factors of user attitude towards the use of MBRS. Accounting practitioners has been choose as unit analysis of this study. The data was collected based on multiple response questionnaire and analysed by using Statistical Package for the Social Sciences (SPSS). The findings of this study shows that perceived usefulness, and perceived ease of use are the factors influencing the attitude of the accounting practitioners to use MBRS.
\end{abstract}

Key words: Malaysian Business Reporting System. MBRS, XBRL, Accounting practitioners, Submission platform, Attitude, Perceived ease of use, Perceived usefulness, Malaysia

\subsection{INTRODUCTION}

Extensible Business Reporting Language is a metalanguage based on XML which communicate the business information into different electronic communication. According to the XBRL International, on 2018 [1] about 8 million filers submit their filing using Extensible Business Reporting Language (XBRL) format to business registrars in 20 countries such as United State, Korea, China and Singapore. The unique tagging structure in XBRL has become the main reason this countries encouraged filing submission in XBRL format to make sure that the submitted reporting transaction are accurate, reliable, efficient in process and to promote new paperless environment $[2][3][4][5]$.

In Malaysia, in line with Companies Commission of Malaysia (SSM) Strategic Direction II (SDP II), SSM has taken the initiative to adopt XBRL in their submission process by introducing a special project known as MBRS project since 2010. After four years, the first financial statement taxonomy known as SSM Taxonomy (SSMxT) has been created and introduced to the public. Finally, on 27 September 2018, SSM has successfully complete this project by launching the new submission platform based on
XBLR format known as Malaysian Business Reporting System (MBRS). SSM has encouraged Malaysian companies to submit their financial statement (FS), annual return (AR), and exemption application (EA) in XBRL format via this MBRS platform. According to SSM, by beginning November 2018 it will be mandatory for unaudited financial statements and Certificate for Exempt Private Company (EPC) to submit their annual statements through online submission using this MBRS platform. For other type of companies, the submission using MBRS are on voluntary basis first but it will become mandatory soon [6].

By submitting using MBRS, both companies and regulators can reduce time and cost especially in the process of gathering financial and non-financial information especially for application and authority related decision-making process. Besides that, MBRS will also give a benefit to other parties related to the companies reporting such as financial statement preparers, auditors, tax practitioners, accounting and finance professionals due to unique characteristics of XBRL which more accurate and reliable compare to other reporting format such as word, pdf or excel since this type of format can give error in copying and pasting to different system [7]. 
However, since the introducing of SSMxT in 2014, the issue of XBRL format adoption by companies in XBRL format. A study conducted by Azleen on 2015 found that no companies prepare their report in XBRL format and they are preferred to prepared report in traditional format such as pdf, excel or word due to low cost and less technical expert requirement [8]. They also feels that XBRL format is too complex to understand compare to traditional format (Ilias, 2015). Due to above matters, the users feels reluctant to use and prepare report in XBRL format. This will give an effect to the future adoption of MBRS submission platform since all submission filing must be submit in XBRL format.

Therefore, the purpose of this study is to examine factors of user attitude towards the use of MBRS. Accounting practitioners has been choose as unit analysis of this study because accounting practitioners are the potential user of MBRS submission platform in the future. TAM theory suggests that perceived usefulness and perceived ease of use [9][10][11][12][13] factors could explain the meaning of attitude of accounting practitioners to use MBRS.

The findings of this study may be useful for the Malaysian government (through SSM) to empirically understand what is the factors that influence accounting practitioner's attitude towards the use of MBRS and help them to find the best way to improve the attitude of accounting practitioners to use MBRS in the future. For the literature perspective, this study will also enhance the empirical understanding of TAM theory especially regarding the accounting practitioners and MBRS.

\subsection{Research Objectives.}

The general objective of this study is to identify the attitude of accounting practitioners in Malaysia to use MBRS. The specific objectives of this studies are as follows:

I. To determine the relationship between perceived ease of use with attitude of accounting practitioners in Malaysia to use MBRS

II. To examine the relationship between perceived usefulness with attitude of accounting practitioners in Malaysia to use MBRS.

\subsection{Research Questions.}

To achieve the objectives, this study will address the following questions:

I. What is the relationship between perceived ease of use with attitude of accounting practitioners in Malaysia to use MBRS?
Malaysia is still questionable especially regarding the attitude of potential users towards the use of

II. What is the relationship between perceived usefulness with attitude of accounting practitioners in Malaysia to use MBRS?

\subsection{LITERATURE REVIEWS}

\subsection{Malaysian Business Reporting System.}

At present, towards author knowledge, there is very limited empirical study has been conduct on area of MBRS. MBRS is a new system consist of three components, which is SSM Taxonomy (SSMxT), MBRS preparation tool (Mtool) and MBRS Portal (Mportal) [6]. SSMxT is a dictionary of financial and nonfinancial reporting element in XBRL taxonomy, which embedded in Mtool. Mtool is a preparation tools based on Microsoft Excel that allow companies to prepare documents (via online or offline) and able to generated annual return, financial statement and exemption application in XBRL format. While for Mportal, is a submission platform to lodge financial statement, annual return and exemption application to SSM. They also can make inquiry, check status and make necessaries related payment system via online. [14]. By beginning November 2018 it will be mandatory for unaudited financial statements and Certificate for Exempt Private Company (EPC) to submit their annual statements through online submission to the SSM using the MBRS platform. For other type of companies, the submission using MBRS are on voluntary basis first but it will become mandatory soon [6].

According to Datuk Zahrah Abd Wahab Fenner, the CEO of SSM, the project of MBRS submission platform would benefit for about 600,000 companies in Malaysia [15]. MBRS is expected to improve the public delivery system, reducing business costs for companies and expedites the updating of information, data exchange, enforcement, and information dissemination to stakeholders [14]. Previously, the companies have to come to SSM office to submit all documents. The documents then will be scan manually, and SSM workers will manually handle the data. By using MBRS, this redundancy clerical work and manually operations will be eliminating [6]. Datuk Zahrah Abd Wahab Fenner also stated that MBRS is also being develop and design with sourced and manage suitable infrastructure to ensured that the system is allow with high availability and disaster recovery [15]. This is to ensure that the companies did not worry about losing their data once it has been upload. The contract to develop MBRS has been given to OMESTI to ensure the successful of this implementation project [16]. Besides that, OMESTI 
group has also been trusted to provide training to all Malaysian companies especially prepares of the financial statement such as accountant on how to use MBRS. The 1 day's intensive training has been conducted to educate prepares regarding the MBRS component and how to prepare and filing using MBRS submission platform [16].

\subsection{Research model and hypothesis development.}

Attitude (AT) is a motor concept or the physical expression of an emotion which refers to the degree of a person has a favorable and unfavorable evaluation or appraisal of the behavior in question [17]. According to the [18], AT also can be defined as the perceived degree of positive and negative feelings about doing the target behavior. In this study, AT can be define as "physical expression of an emotion which refers to perceived degree of positive and negative feelings about using MBRS". According to TAM theory, the use of technology depends on the intention (BI), and intention to use depends on the attitudes towards it's (AT) [19][5][20][13]. In TAM, this AT formed by an assessment of two variables, which is the PEOU and the PU towards the technology. Below is the conceptual framework for this study.

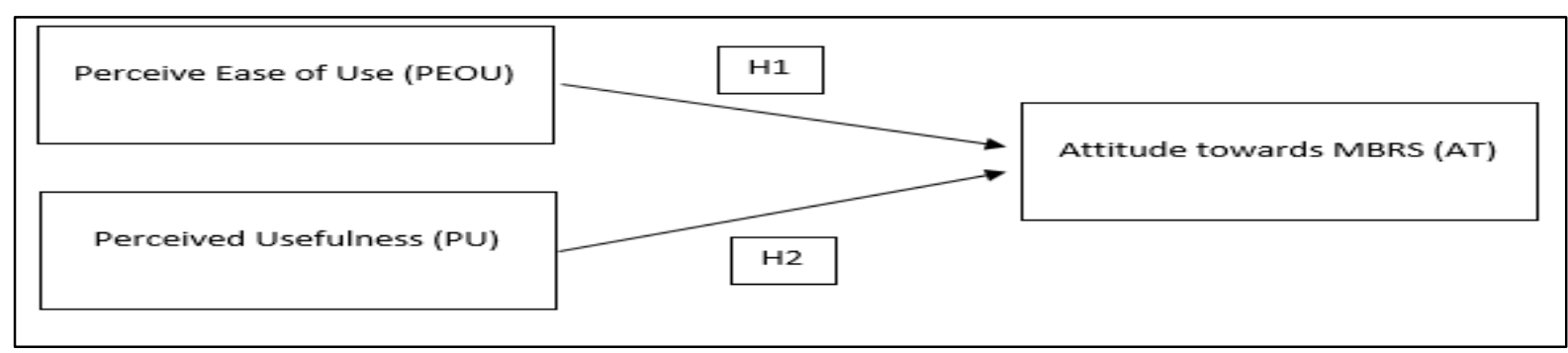

Figure 1: Conceptual framework

2.6.1 The relationship between perceived ease of use (PEOU) and attitude (AT) towards using MBRS.

The term PEOU is the concept that represent an assessment of the degree to which interaction with a system or a specific information technology is free of mental effort [21][11]. For context of this study, PEOU is define as "the degree to which individuals feel free from engaging in mental and physical efforts in using MBRS."

In TAM both PU and PEOU have been tested in many areas to describe or predict attitude and behavioral intention on different technologies such as e-banking, e-commerce, e-learning, e-library, etax filing, telemedicine technology, word processing, social networking media, smartcard and microcomputer. An empirical research has found that both of this variable has a positive relationship towards attitude and behavior intention. [9][10][11][12][13].

A research conducted by Yoon, [13] has found that PEOU had significant effects on user AT towards new system application in library at Joongbu University. A research conducted by Muñoz-Leiva et al., [22] found that PEOU has a significant positive relationship with AT towards new mobile banking application system. Research by $\mathrm{Yu}, \mathrm{Yi}$, Liu, \& Feng, [23] also found that AT toward use of Commercial Bike-sharing Systems was positively affected by PEOU. Additionally, a study by Sarika, Preeti, Shilpy, \& Sukanya, [24] found that PEOU of the system has a positive relationship towards AT to shop online. From above literature, it shows that, most of the study found positive relationship between PEOU and AT in technology adoption. The more PEOU towards system the more positive AT towards using the system.

However a research conducted by Sabir, Ahmad, \& Noor, [25] found that there were negative relationship between AT and PEOU in Social Networking Sites (Facebook) system among Pakistani university students. They found Pakistani students are not attracting towards enjoyment of using Facebook and the acceptance of technology is widely affected by their society social norm. From that, it shows mix findings regarding the relationship between PEOU and AT towards technology. Thus, hypothesis $\mathrm{H}_{1}$ was propose:

$H_{1}$ : There is a positive and direct significant relationship between perceived ease of use (PEOU) and attitude towards using MBRS (AT).

2.6.2 The relationship between perceived usefulness (PU) and attitude (AT) towards using MBRS.

PU can be defining as the perception of individuals with regard to the improvement of the tasks performed when using the system in question [26][11]. In this study, PU defined as "perception of individual's practitioners with regard to the improvement of the tasks performed when using MBRS in question". 
Many researchers have found positive relationship between PU and AT. A study conducted by Yu et al., [23] found that PU is significant towards AT to use commercial bike-sharing systems. A research conducted by Yoon, [13] has found that PU had significant effects on AT towards new system application in library at Joongbu University. A study conducted by Sarika et al., [24] also found that PU has significant impact on AT to shop online. Its shows that, the more PU towards system the more they would positive AT towards using the system. However, a study conducted by Sabir et al., [25] found that PU has not been verified to be a major

\subsection{METHODOLOGY}

\subsection{Research Design.}

This study was conducted with the intention to obtain a good grasp of the determinants factors of accounting practitioners attitude towards the use of MBRS. This study is a quantitative research where the questionnaire will be used and been analyzed in numerical data to answer the research questions. This study also was a cross-sectional study where data was gathered once. A survey method was been use because this study strongly believes that survey research is best adapted to obtain personal and social facts, beliefs, and attitudes [26].

The scope of this study was focusing to the individual person who potentially will use MBRS system. Individual accounting practitioner's in various accounting field job such as financial statement prepares, auditors, tax practitioners, accounting professional, finance professionals are the person who potentially will involve in using, reviewing, submitting using this MBRS systems. Since MBRS was enforce and centralized control by SSM, there is no different in MBRS function system even though user use MBRS in different state in Malaysia. For this reason, the author has decided to select individual practitioners who practicing in area of Wilayah Persekutuan Kuala Lumpur, Selangor, Pulau Pinang, Perak, Kedah and Kelantan as unit analysis for this study.

This six state mentioned above has been randomly selected by author from total 14 state in Malaysia to get a multiple respond from various respondent in Malaysia. This state has been selected by the author element in examining BI to use Facebook among Pakistani university student. They found that the higher PU would not lead to positive AT towards using Facebook. PU will not change AT in using Facebook among Pakistani university student. Therefore, hypothesis $\mathrm{H}_{2}$ was propose:

$\mathrm{H}_{2}$ : There is significant positive relationship between perceived usefulness (PU) with attitude (AT) towards using MBRS.

using convenience sampling methods. However, only accounting practitioners who practicing in the city area of this state are taken as sample respondent. The main reason author decided to focus more on city area is because in city area they are many business activities involve compare to rural area. Besides that, the information regarding the implementations of MBRS is highly receive in this city area compared to rural area. Each individual response will be treated as an individual data source.

3.2 Measurement of the survey questionnaire.

One advantage of using the TAM theory to study new technologies acceptance is that it has a wellvalidated measurement inventory [21]. Measures for the various constructs were drawn out from survey items in the previous literature and adapted to the specific MBRS study settings. All items were asked on a 1 to 5 Likert scale anchored by $1=$ "strongly disagree" to $5=$ "strongly agree".

Studies on perceived usefulness, perceived ease of use, and attitude toward using have been well researched, especially in the context of TAM applications. Measurement for these constructs have been well developed, validated and adopted in many technology adoption studies. All variables included in this study were measured on multiple item scales drawn from previous research. However, phrasing will be adapted to suit with the sample and local setting. Table 3.2.1 below is the multiple item measures for each construct for this study. 
Table 3.2.1: multiple item measures for each construct for this study.

\begin{tabular}{|c|c|c|}
\hline Variable & Original Source & Modified item \\
\hline \multirow{6}{*}{$\begin{array}{l}\text { Perceived } \\
\text { usefulness } \\
\text { (6 Items) }\end{array}$} & \multirow[t]{6}{*}[10]{$[22][13]$} & 1. Using MBRS enables me to submit financial report on time. \\
\hline & & 2. Using MBRS can save my time in reporting process. \\
\hline & & $\begin{array}{l}\text { 3. Using MBRS allow me to manage business report in an efficient } \\
\text { way. }\end{array}$ \\
\hline & & 4. Using MBRS improves the quality of business report. \\
\hline & & $\begin{array}{l}\text { 5. Using MBRS enables me to improve report for decision making } \\
\text { process. }\end{array}$ \\
\hline & & 6. Overall, I think MBRS is useful. \\
\hline \multirow{8}{*}{$\begin{array}{l}\text { Perceived } \\
\text { ease of use } \\
(8 \text { items })\end{array}$} & \multirow[t]{8}{*}[10]{$[22][13]$} & 1. Learning to use MBRS does not require much mental effort. \\
\hline & & 2. I find it easy to access and use MBRS when and where I want. \\
\hline & & 3. My interaction with MBRS is clear and understandable \\
\hline & & 4. Learning to use MBRS is so easy for me. \\
\hline & & 5. I find MBRS are flexible to interact \\
\hline & & 6. I find the procedure of using MBRS is understandable. \\
\hline & & 7. The tool in MBRS is easy to use in general \\
\hline & & 8. Overall, I find MBRS easy to use. \\
\hline \multirow{5}{*}{$\begin{array}{l}\text { Attitude } \\
\text { toward using } \\
\text { (5 items) }\end{array}$} & \multirow[t]{5}{*}[22]{$[13]$} & 1. Using MBRS is such a wonderful idea. \\
\hline & & 2. I would have positive feelings toward MBRS in general. \\
\hline & & $\begin{array}{l}\text { 3. It is easier and better for me to use MBRS, as compared to a manual } \\
\text { submission system. }\end{array}$ \\
\hline & & 4. Nowadays, online submission platform such as MBRS is a must. \\
\hline & & 5. Overall, I in favor to use MBRS. \\
\hline
\end{tabular}

3.3 Sample and Data Collection Procedures.

According to Accountant General's Department of Malaysia on 2014, there about 36,000 accounting practitioners in Malaysia and it is estimated that by the year 2020, Malaysia will need 60,000 professional accountants to serve the need of a developed economy in order to ensure Malaysian enterprises remain competitive and resilient [27]. Based on the above statement it safe to conclude that 36,000 is the total number of populations for accounting practitioners in Malaysia.

Roscoe, [28] stated that to determine the sample size, we can use the rule of thumb by multiplying the number of variables in the study framework with 10 [29]. In this study the total variable is 5 multiplying with 10 so the minimum sample needed will be 50 .

However, if the sample size is too small it may not give accurate results and will not represented the whole populations. Size of sample collection is important aspects because it will affect the reliability and validity of the study [29].
Krejcie \& Morgan, [30] proposed estimation table to determine sample size base on the population. Based on Krejcie \& Morgan, [30] estimation table, 380 number of sample are suggested in this study. However, the author has decided to increase 5.3\% more (20 sample) from suggested sample size to increase the reliability and validity of this study. The total number of samples for this study is $400(380+$ 20) number of samples. The survey questionnaires then were manually distribute by author. A total 4 weeks has been taken by author to distribute the survey questionnaire.

Before deciding on the actual instrument to be utilized in this study, a pilot study has been conducted using a convenience sample of 30 practitioners from randomly audit firm, accounting firm and company secretary in Alor Setar Kedah. The researcher was with the respondents while they completed the questionnaire to identify difficulties in wording, to answer respondents' questions and generally to check on the ease of completion. After that, the reliability test for each instrument was 
calculated using the pilot study data by identify the cronbach's alpha value. The cronbach alpha value is found ranged from 0.949 to 0.973 and it is are generally considered enough for research purposes [31][29]. Non response biasness test also been run using T-test to see the different between early and late respond [32]. The result shows that there is no from SPSS (The Statistical Package for Social Science) software version

\subsection{DATA ANALYSIS}

\subsection{Response Rate.}

In this study, 400 questionnaires were manually distributed to all individual accounting practitioners. However, only 177 were returned, and 8 were found incomplete. Thus, a total of 169 responses were usable and used for subsequent analysis, giving a response rate of $42.25 \%$. Even though the response rate was below $50 \%$, it is still considered adequate for the analysis [33]. Table 4.1.1 below summarizes the questionnaires distribution and response

Table 4.1.1: Questionnaire distribution and response

\begin{tabular}{|l|l|}
\hline Questionnaires / Response & Frequency / Rate \\
\hline $\begin{array}{l}\text { Number of manually } \\
\text { distributed questionnaires }\end{array}$ & 400 \\
\hline Return questionnaires & 177 \\
\hline Incomplete response \& & 8 \\
\hline $\begin{array}{l}\text { Total for } \\
\text { questionnaires use } \\
\text { analysis }\end{array}$ & $\begin{array}{l}\text { 44.47\% (30\% and } \\
\text { more considered } \\
\text { sufficient } \\
\text { according to } \\
\text { Sekaran, [32]). }\end{array}$ \\
\hline
\end{tabular}

\subsection{Data Screening and cleaning.}

Before further data analysis, all the data will be screening or cleaning to ensure the appropriateness of the data for statistical analysis by check whether the raw data are missing, out of range and outliers [34][35]. In this study, 8 responses were incomplete and has been removed. Missing data frequently happen when the respondent not able to completely reply questions in a survey [36].

A univariate outlier is a data point that consists of an extreme value on one variable. A multivariate outlier is a combination of unusual scores on at least two variables. Both types of outliers can influence the outcome of statistical analyses.

Univariate outliers' analysis was performed by identifying the value of $\mathrm{Z}$-scores. If the $\mathrm{Z}$-score significant different between this two group. Therefore, we can conclude that non-response bias has no significant effect in generalizing the findings of this study. For the purpose of data analyses and hypotheses testing, several statistical methods were employer

greater than \pm 3.0 , the selected items will be considered univariate outliers [37]. While for, multivariate outliers, the Mahalanobis distances test will be used. Tabachnick BG \& Fidell LS, [37] stated that, if the value of probability variable less

than 0.001 , it indicates the multivariate outliers. Table 4.2.1 below summarizes the outliers and the total number of data used for further analysis.

Table 4.2.1: The total number of data used for further analysis

\begin{tabular}{|l|l|}
\hline Questionnaires / Response & $\begin{array}{l}\text { Frequency / } \\
\text { Rate }\end{array}$ \\
\hline $\begin{array}{l}\text { Total response \& questionnaires } \\
\text { use for analysis }\end{array}$ & 169 \\
\hline $\begin{array}{l}\text { Univariate Outliers } \\
\text { (Z-score greater than } \pm 3.0 \text { [36]). } \\
\text { (Item } \\
34,53,66,87,100,102,133,136 \text { and } \\
\text { 138) }\end{array}$ & 9 \\
\hline $\begin{array}{l}\text { Multivariate outliers } \\
\text { (Mahalanobis distances test. value } \\
\text { of probability variable less than } \\
\text { O.001, [37]). } \\
\text { (Item no 67 and 52) }\end{array}$ & 2 \\
\hline $\begin{array}{l}\text { Total Data available for further } \\
\text { analysis }\end{array}$ & 158 \\
\hline
\end{tabular}

\subsection{Reliability Test.}

Reliability analysis is used to measure both consistency and stability of variables. Consistency and stability specifies how well the items measuring a concept hang together as a set. If the outcomes of a research be able to be replicated in an analogous approach, the research instrumentation is reflected to be reliable [29]. This study use coefficient alpha to estimate internal consistency reliability. If the reliability less than 0.60 is considered to be poor, those in the 0.70 range is acceptable, and those over 0.80 are good. [29] For the purpose of the present study, a minimum reliability (Cronbach's Alpha) value of 0.60 was set, which is the threshold recommended by Nunnally, [31] and Sekaran \& Bougie, [29]. 
The Cronbach's alpha result is 0.953 (more than 0.6) as shown in Table 4.3.1 below indicate that the reliability is good. The Cronbach's alpha if item deleted estimates ranged from 0.936 to 0.944 are lower than the overall Cronbach alpha 0.953. It showed that if the construct been deleted, the Cronbach alpha will be drop less than 0.953. It indicates that the scales can be regarded as relatively as good and reliable. [31][29].

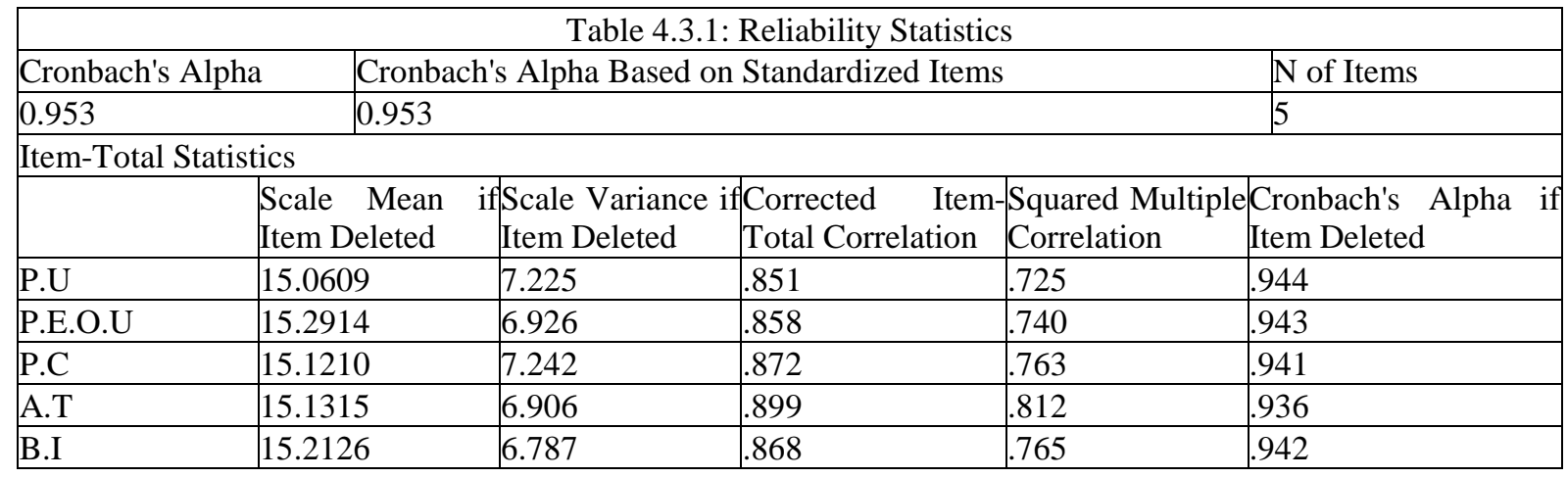

4.4 Regression Analysis.

The main purpose of conducting regression analysis is to examine the hypothesis where the statistical meaning can be examined and form of the interaction term whilst it used to show correlation coefficients and the strength between the relationship of independent variable and dependent variable. The linear regression analysis was adopted to clarify the relationship between the variables as a whole model. In this study they is no autocolinearity and multicollinearity problem and all data are distributing normally. Therefore, the regression analysis can be done.

Table 4.4.1. shows the $\mathrm{R}$ square value is 0.735 . It indicates that both variable (PU and PEOU) can explained $73.5 \%$ of variance in AT of accounting practitioners to use MBRS and $26.5 \%$ of variance are explain by others factors.

\begin{tabular}{|c|c|c|c|c|c|}
\hline \multicolumn{6}{|c|}{ Table 4.4.1.: Model Summary } \\
\hline Model & & $\mathrm{R}$ & R Square & Adjusted R Square & Std. Error of the Estimate \\
\hline dimension0 & 1 & $.857^{\mathrm{a}}$ & .735 & .731 & .37382 \\
\hline \multicolumn{6}{|c|}{ a. Predictors: (Constant), P.E.O.U, P.U } \\
\hline
\end{tabular}

Table 4.4.2 it shows that the F value 214.745 and significant value 0.000 (less than 0.05 ) indicate that there are highly significant.

\begin{tabular}{|c|c|c|c|c|c|c|}
\hline \multicolumn{7}{|c|}{ Table 4.4.2: ANOVA $^{\mathrm{b}}$} \\
\hline Model & & Sum of Squares & df & Mean Square & $\mathrm{F}$ & Sig. \\
\hline \multirow[t]{3}{*}{1} & Regression & 60.018 & 2 & 30.009 & 214.745 & $.000^{\mathrm{a}}$ \\
\hline & Residual & 21.660 & 155 & .140 & & \\
\hline & Total & 81.678 & 157 & & & \\
\hline \multicolumn{7}{|c|}{ a. Predictors: (Constant), P.E.O.U, P.U } \\
\hline b. Deper & able: A.T & & & & & \\
\hline
\end{tabular}


Table 4.5.3. shows that beta value for PEOU is +0.464 and $\mathrm{p}$ value +0.000 (less than 0.05 ). It indicates that PEOU has a positive relationship with AT of accounting practitioners to use MBRS. Therefore, the hypothesis 1 (H1) has been supported.
Meanwhile, the beta value for PU is +0.45 and $\mathrm{p}$ value +0.000 (less than 0.05 ). It indicates that $\mathrm{PU}$ also has a positive relationship with attitude of accounting practitioners to use MBRS. Therefore, the hypothesis 2 (H2) has also been supported.

\begin{tabular}{|c|c|c|c|c|c|c|}
\hline \multicolumn{7}{|c|}{ Table 4.5.3: Coefficients ${ }^{\text {a }}$ (First Model) } \\
\hline \multirow[t]{2}{*}{ Model } & & Unsta & Coefficients & $\begin{array}{l}\text { Standardized } \\
\text { Coefficients }\end{array}$ & & \\
\hline & & $\mathrm{B}$ & Std. Error & Beta & $\mathrm{t}$ & Sig. \\
\hline \multirow[t]{3}{*}{1} & (Constant) & .371 & .173 & & 2.143 & .034 \\
\hline & P.U & .450 & .071 & .428 & 6.367 & .000 \\
\hline & P.E.O.U & .464 & .065 & .478 & 7.107 & .000 \\
\hline
\end{tabular}

\section{$\underline{4.5 \text { Summary of hypothesis testing result }}$}

Table 4.5.1 below will conclude the hypothesis testing

\begin{tabular}{|l|l|l|}
\hline Research question & Hypothesis & Result \\
\hline $\begin{array}{l}\text { RQ 1: What is the relationship between } \\
\text { perceived ease of use with attitude of } \\
\text { accounting practitioners in Malaysia to use } \\
\text { MBRS? }\end{array}$ & $\begin{array}{l}\text { H1: There is significant positive between } \\
\text { perceived ease of use with attitude of } \\
\text { accounting practitioners in Malaysia to use } \\
\text { MBRS. }\end{array}$ & Supported \\
\hline $\begin{array}{l}\text { RQ 2: What is the relationship between } \\
\text { perceived usefulness with attitude of } \\
\text { accounting practitioners in Malaysia to use } \\
\text { MBRS? }\end{array}$ & $\begin{array}{l}\text { H2: There is significant positive } \\
\text { relationship between perceived usefulness } \\
\text { with attitude of accounting practitioners in } \\
\text { Malaysia to use MBRS. }\end{array}$ & Suported \\
\hline
\end{tabular}

\subsection{CONCLUSION}

From the analysis results, it's showed that perceived usefulness, and perceived ease of use are the factors influencing the attitude of the accounting practitioners to use MBRS. This is answerable in hypothesis 1 and 2 in this study. Both result shows that they were significantly positive relationship which indicate that if the perceived usefulness and perceived ease of use towards MBRS are increase it will also improve the attitude of accounting practitioners to use MBRS. These findings consistent with the findings by many researchers especially in the context of behavior study in technology adoption and TAM theory. [9][10][11][22][12][13].

From this results, it is advisable to SSM to increase perceived usefulness and perceived ease of use

\subsection{REFERENCES}

[1] XBRL International. (n.d.). An Introduction to XBRL. Retrieved from https://www.xbrl.org

[2] Bai, Z., Sakaue, M., \& Takeda, F. (2014). The Impact of XBRL Adoption on theInformation Environment: Evidence from Japan. The Japanese factors such as conducting an intensive training, provide more seminar to educate the accounting practitioners, providing more guiding reference, and consistently improving MBRS to become more user friendly in order to improve the attitude of accounting practitioners to use MBRS. Therefore, the responsible parties comprising the government and authorities are advisable to focus more on this factors in order to make sure that the adoption of the MBRS system by accounting practitioners in the future are good in order to go one step further in new digitalized reporting era.

Accounting Review, 4(2014), 49-74. https://doi.org/10.11640/tjar.4.2014.03

[3] Bonsón, E., Cortijo, V., \& Escobar, T. (2009). A Delphi Investigation to Explain the Voluntary Adoption of XBRL1. The International Journal of Digital Accounting ..., 9(November), 193-205. https://doi.org/10.4192/1577-8517-v9 
[4] Dong, Y., Li, O. Z., Lin, Y., \& Ni, C. (2016). Does Information-Processing Cost Affect FirmSpecific Information Acquisition? Evidence from XBRL Adoption. Journal of Financial and Quantitative Analysis, 51(2), 435-462. https://doi.org/10.1017/S0022109016000235

[5] El-Sherbini, E. E. F., Wahaab, S. M. A., \& Deyab, M. (2005). Ethoxylated fatty acids as inhibitors for the corrosion of zinc in acid media. Materials Chemistry and Physics, 89(2-3), 183-191.

https://doi.org/10.1016/j.matchemphys.2003.09.055 [6] Suruhanjaya Syarikat Malaysia (SSM). (2019). Pengumuman berhubung pelaksanaan serah simpan penyata tahunan dan penyata kewangan melalui portal Malaysian Business Reporting System (MBRS), (September 2018), 7721.

[7] Suruhanjaya Syarikat Malaysia (SSM). (n.d.-b). MBRS for preparers - financial statements introduction to mbrs.

[8] Ilias, A. (2015). The Existence of the Extensible Business Reporting Language ( XBRL ) In Malaysia: From A Stakeholders ' Perspective, (FEBRUARY 2014), 1-49.

[9] Elkaseh, A. M., Wong, K. W., \& Fung, C. C. (2016). Perceived Ease of Use and Perceived Usefulness of Social Media for e-Learning in Libyan Higher Education: A Structural Equation Modeling Analysis, (September 2015). https://doi.org/10.7763/IJIET.2016.V6.683

[10] Gangwar, H., Date, H., \& Ramaswamy, R. (2015). Understanding determinants of cloud computing adoption using an integrated TAM-TOE model. Journal of Enterprise Information Management, 28(1), 107-130. https://doi.org/10.1108/JEIM-08-2013-0065

[11] Jahangir, N., \& Begum, N. (2008). The role of perceived usefulness, perceived ease of use , security and privacy, and customer attitude to engender customer adaptation in the context of electronic banking, 2(1), 32-40.

[12] Venkatesh, V., \& Davis, F. D. (2000). A Theoretical Extension of the Technology Acceptance Model: Four Longitudinal Field Studies. Management Science, 46(2), 186-204. https://doi.org/http://dx.doi.org/10.1287/mnsc.46.2. 186.11926

[13] Yoon, H. Y. (2016). User Acceptance of Mobile Library Applications in Academic Libraries: An Application of the Technology Acceptance Model. Journal of Academic Librarianship, 42(6), 687-693. https://doi.org/10.1016/j.acalib.2016.08.003
[14] Suruhanjaya Syarikat Malaysia (SSM). (n.d.-a). Malaysian Business Reporting System (MBRS) Frequently Asked Questions.

[15] Radhi, N. A. M. (n.d.). Mandatory for companies to submit their documents to SSM via new platform soon. New Straits Times Press (M) Bhd.

[16] Services, F. N. (n.d.). MBRS Financial Statements MBRS for preparers: financial statements hands - on training for mtool submission of financial statements \& key.

[17] Oly Ndubisi, N., \& Sinti, Q. (2006). Consumer attitudes, system's characteristics and internet banking adoption in Malaysia. Management Research News, 29(2000), 16-27. https://doi.org/10.1108/01409170610645411

[18] Fishbein, M., \& Ajzen, I. (1975). Belief, Attitude, Intention and Behaviour: An Introduction to Theory and Research. Reading MA AddisonWesley, (May 1975), 480. https://doi.org/10.2307/2065853

[19] Agrebi, S., \& Jallais, J. (2015). Explain the intention to use smartphones for mobile shopping. Journal of Retailing and Consumer Services, 22, 16-23.

https://doi.org/10.1016/j.jretconser.2014.09.003

[20] Shiau, W. L., \& Chau, P. Y. K. (2016). Understanding behavioral intention to use a cloud computing classroom: A multiple model comparison approach. Information and Management, 53(3), 355-365. https://doi.org/10.1016/j.im.2015.10.004

[21] Davis, F. D. (1989). Perceived Usefulness, Perceived Ease of Use, and User Acceptance of Information Technology. MIS Quarterly, 13(3), 319. https://doi.org/10.2307/249008

[22] Muñoz-Leiva, F., Climent-Climent, S., \& Liébana-Cabanillas, F. (2017). Determinantes de la intención de uso de las aplicaciones de banca para móviles: una extensión del modelo TAM clásico. Spanish Journal of Marketing - ESIC, 21(1), 25-38. https://doi.org/10.1016/j.sjme.2016.12.001

[23] Yu, Y., Yi, W., Liu, J., \& Feng, Y. (2018). Understanding the Intention to Use Commercial Bike-sharing Systems : An Integration of TAM and TPB, 9, 646-655.

[24] Sarika, K., Preeti, S., Shilpy, S., \& Sukanya, S. (2015). A Study of Adoption Behavior for Online Shopping : An Extension of Tam Model. 
[25] Sabir, R. I., Ahmad, W., \& Noor, N. (2013). Adoption of Social Networking Sites among Pakistani University Students : A Case of, 3(6), 125139.

[26] Kerlinger, F. N. (1973). Foundations of Behavioural Research. (2nd edition). New York: Holt, Rinehart \& Winston.

[27] The Committee to Strengthen the Accountancy Profession. (2014). Report on the strengthening of the accountancy profession in malaysia. Jabatan Akauntan Negara.

[28] Roscoe, J. T. (1975). Fundamental Research Statistics for the Behavioral Science (2nd edition). New York: Holt, Rinehart \& Winston.

[29] Sekaran, U., \& Bougie, R. (2016). Research methods for business: A skill building approach. John Wiley \& Sons.

[30] Krejcie, R. V, \& Morgan, D. W. (1970). Determining Sample Size for Research Activities. Educational and Psychological Measurement, 30(3), 607-610. https://doi.org/10.1177/001316447003000308

[31] Nunnally, J. C. (1978). Psychometric Theory (2nd ed). New York: McGraw Hill Book Company.

[32] Armstrong, J. S., \& Overton, T. S. (1977). Estimating Nonresponse Bias in Mail Surveys. Journal of Marketing Research, XIV, 396-402

[33] Sekaran, U. (2003). Research Methods For Business: A Skill Building Approach (4th ed.), New York: John Willey \& Sons.

[34] Hair, J., Black, W., Babin, B., \& Anderson, R. (2010). Multivariate data analysis: International version, New Jersey, Pearson.

[35] Pallant. (2007). A step by step guide to data analysis using SPSS for windows version 15.

[36] Little, R. J. A., \& Rubin, D. B. (2002). Statistical Analysis with Missing Data (2nd edition). John Wiley \& Sons, Inc. https://doi.org/10.2307/3172915

Mooi, E., \& Sarstedt, M. (2011). A concise guide to market research, capítulo 9,“Cluster analysis." Springer.

[37] Coakes, S., \& Steed, L. (2003). Multiple response and multiple dichotomy analysis,SPSS, John Wiley \& Sons, Australia Milton.
[38] Tabachnick BG, \& Fidell LS. (2007). Using Multivariate Statistics (5th Ed.). Boston: Pearson. (p. 74). 